A Journal of Culture, English Language, Teaching \& Literature ISSN 1414-3320 (Print), ISSN 2502-4914 (Online)

Vol. 19 No.2; December 2019

Copyright (C) Soegijapranata Catholic University, Indonesia

Students' Perception Towards the Use of Edmodo In OnlineBased English Learning Class at Universitas Fajar

Andi Febriana Tamrin

English Literature Department, Faculty of Economic and Social Sciences, Fajar University, Makassar, Indonesia

email: andifebriana90@unifa.ac.id

Received: 22-10-2019

Accepted: 11-11-2019

Published: 7-12-2019 


\title{
Students' Perception towards the Use of Edmodo in Online- Based English Learning Class at Universitas Fajar
}

\author{
${ }^{1}$ Andi Febriana Tamrin \\ 1ªndifebriana90@gmail.com \\ ${ }^{1}$ Department of English Literature, Faculty of Economics and \\ Social Sciences, Universitas Fajar, Makassar, Indonesia
}

\begin{abstract}
Online-based learning or lecture is deemed as a new learning methodology among academics in this present era. This method involves a learning process in which lecturers and students could undergo lectures or courses without being present in the classroom. One of the online applications that supports this method is Edmodo. This study aims to obtain data about the perception of students regarding the use of Edmodo in English language classes at Universitas Fajar. The method used in this study is descriptive study. The result showed that although it has drawbacks, Edmodo is considered as one of the most effective tools in supporting the learning process.
\end{abstract}

Key words: Edmodo, English class, perception

Abstrak: Pembelajaran online atau perkuliahan secara daring dapat diasumsikan sebagai sebuah paradigma baru yang berada di kalangan akademisi. Metode ini berupa proses pembelajaran yang dalam proses belajar mengajar (PBM) dimana dosen dan mahasiswa dapat melakukan perkuliahan tanpa harus duduk di ruang yang untuk melakukan aktivitas kelas. Salah satu aplikasi yang mendukung kegiatan ini Edmodo. Penelitian ini bertujuan untuk mendapatkan data mengenai persepsi mahasiswa mengenai penggunaan Edmodo dalam proses belajar di kelas Bahasa Inggris di Universitas Fajar. Metode yang digunakan dalam penelitian ini adalah metode deskriptif presentase. Hasil penelitian menujukkan bahwa Edmodo dianggap sebagai salah satu media pendukung pembelajaran yang efektif bagi mahasiswa. 
Tamrin, A. F., Students' Perception towards the Use of Edmodo in Online- 303 Based English Learning Class at Universitas Fajar

Meski demikian, pembelajaran dengan menggunakan metode ini masih ada kendala dalam hal pengoperasiannya bagi mahasiswa.

Kata kunci: Edmodo, kelas bahasa inggris, persepsi

\section{INTRODUCTION}

There are three important factors that must be considered in planning a learning process, namely; learning condition, method and result. Out of these, method of learning is the one that could be modified by the lecturer or teacher. In method of learning, lecturers could implement many methods to achieve learning outcomes in accordance with the learning conditions. Method and medium of learning are the two most prominent components in a learning process as they serve as the primary tool in pedagogical practices. In terms of role, they both have interrelated function in learning.

The use of technology in the learning process encourages the lecturers to create a variety of learning media or medium to apply in their learning process. The idea of using animation to explain complicated case for students to learn and use video conference in classroom as part of a learning process is very interesting for learning practitioners. It is also because there is progress in the field of information technology (IT) that created a new concept in learning process, which is called e-learning.

Online study or e-learning is an internet-based learning method that connects teachers and students who are in different places. The use of elearning terminology refers to all training or educational activities that implemented electronic media or information technology in the learning process. Bentley, Y., Habte, S., and Anjali Shegunshi. (2012). Design and Evaluation of Student-Focused eLearning. The Electronic Journal of eLearning, Volume 10 Issue I, 2012, page 1-12 from http://www.ejel.org/volume10/issue1 suggested that online study is a modern learning method that connects lecturers and students who are in different places. This phenomenon gains considerable attention in the field of education and training and sparks the existence of e-learning method.

The medium of learning serves as a supportive tool to assist learning process that could be accessed and used by teachers, and online media has been increasingly used in schools and 
universities nowadays. On of the online applications that is used to support the learning process is Edmodo, a learning application that was developed by Jeff O'Hara and Nick Borg in 2008 and could be accessed freely. In addition to its easy and flexible use, this application could make learning become more interesting.

With the use of Edmodo, students could interact with their peers and teachers actively in any time and place. Moreover, they could access course materials that are shared through this application, including texts, pictures, sound, data, and video. In addition, it also has some features for creating class group, quiz, poll, and gradebook. In fact, it is a school-based application with social media characteristics, which are supported by a Learning Management System. The LMS which is adjusted with virtual learning need, could give extensive benefits to its users (Balasubramani, Kandappan \& Jaykumar, Leena N.K. (2014). Student Preference Towards the Use of Edmodo as A learning Platform to Create Responsible Learning Environment. Proceeding, Asia Euro Conference. Selangor: School of Hospitality, Tourism and Culinary Arts.. The features that are usually included in LMS are video conference and discussion forum.

One of the courses using this application is English learning and is often deemed highly difficult for students. Attracting students' interest in English classes becomes one of the greatest challenges because teachers often face issues such as monotonous teaching style and lack of learning resources. Hence, studying about online-based learning is necessary to explore the perception of learners on its implementation.

\section{LITERATURE REVIEW}

\section{A. Online Learning}

Online learning, e-learning, or virtual learning is a learning approach that uses internet connections as a basis for learning interaction media. Kucirkova, et al (2012) explains that online learning is a learning process where teachers and students not only sit in one place simultaneously but use internet connection-based technology. Internetbased means that in online learning students and lecturers rely on internet-based technology as a medium of interaction and the provision of 
Tamrin, A. F., Students' Perception towards the Use of Edmodo in Online- 305 Based English Learning Class at Universitas Fajar

teaching materials. In conclusion, online learning is a learning process that uses internet technology media to interact in the learning process.

Nowadays the development of e-learning in the Indonesia education is rapidly evolving. There are several variations of e-learning, ranging from power point in the classroom up the LMS that is developed by a university. Sindu in Basori (2013) states that learning atmosphere could accommodate students in displaying their roles actively to do planning and finding materials for their lesson by themselves.

\section{B. Edmodo}

Balasubramani \& Jaykumar (2014) states that Edmodo is defined as a free and secure social networking-based learning that makes it easy for teachers to create and manage virtual classes, so students can connect with classmates and instructors where and whenever they are. Edmodo was created using a concept similar to Facebook, where the purpose of making it is specifically for the field of education that can support the learning process online. This application not only connects teachers and students but also parents can monitor if they have an account.

Edmodo is a social network-based learning media in supporting the learning process in virtual classrooms. Edmodo provides facilities for sharing material, communicating with friends and teachers and doing assignments online that can be used anytime and anywhere. According to Sanaky (2013), Edmodo has several purposes, it can be seen as:
a. Improving the quality of student learning
b. Changing the culture of teaching
c. Changing student learning styles
d. Expanding learning opportunities for students
e. Developing and expanding new products and services.

Integrating social network, such as Edmodo in the teaching and learning process gives some pedagogical benefits. This is a tool to improve learning because it allows students to give comments, send notes, links, files, warnings, tasks, warnings, events and messages directly to the teacher. Looi \& Yusop (2011) states that Edmodo is for students who are 
weak and introverted, because they can use the platform to interact and communicate with their teachers. The teacher also could clarify their doubts in the subjects studied through the platform. This helps to reduce the inconvenience of having to ask in front of a physical audience. Apart from that, they add that Edmodo provides a motivating learning atmosphere by making it possible for teachers to reward students who perform well in quizzes and assignments with badges.

More importantly, unlike another social networking site such as Twitter and Facebook, Edmodo provides students with a taste community and involvement in their learning with excellent security. Scott (2012) states that Edmodo can be a useful technology for teachers and students as Edmodo is made for free, and can be accessed anytime and anywhere from a computer or a device with an internet connection. It also offers free applications for Apple and Android devices. In addition, through Edmodo, individuals can collaborate on activities or share contents. This facilitate classroom management by offering useful tools for posting jobs, set quizzes, organize groups, manage turn-ins and grade assessments, update calendar, create an upload library and monitoring discussion.

\section{Students' Perception}

Students' perception is the perspective or opinion of students about a matter related to the learning process for example; learning process, teaching material, students' needs and so on. Struyven (2005) explain that students' perceptions are all concepts used to identify students' ideas, beliefs, opinions, images, and preferences about their educational context and educational activities. Based on this explanation, it can be concluded that student perception is a perspective that contains information about education and education activities that should be carried out by teachers based on their perception. Students' perceptions cannot be justified by teachers or policy makers but must be considered, because they can be used as information to develop the quality of education.

Positive teacher-student relationship is known to facilitate conducive classroom climate that will enhance students' learning and interaction in the classroom. A good, positive classroom environment is important because this situation provides the students' opportunities to feel capable, worthy, and confident. With these feelings, the students would feel brave to share, express opinions, ask questions, convey difficulties, and to work 
Tamrin, A. F., Students' Perception towards the Use of Edmodo in Online- 307 Based English Learning Class at Universitas Fajar

without pressure. This condition is supported by Mazer (2012, p. 99 as cited in Da Luz, 2015) who states that students who experience heightened emotional interest are more energized, excited, and emotionally engaged by the material given in the classroom. Nielson \& Lorber (2009) also note that exposure towards positive emotional stimuli will make the students able to recall newly learned information better than those who are not given any stimuli.

\section{METHOD}

This study used descriptive method. Sugiyono (2013) suggested that descriptive method is a method of analyzing data used to respond and describe particular problem objectively. This method was selected as it assisted the researcher to obtain and describe the study finding. This study also used descriptive method for analysis technique, and it was used to gain data about learners' perception towards the use of online-based learning and Edmodo in English classes at Universitas Fajar.

The data were analyzed by selecting, sorting out, and grouping the available data, followed by summarizing and presenting them in the form of narrative. The data were presented in the form of brief description and tables using statistic descriptive and percentage-based analysis.

The respondents of this research are the students who programmed English. They come from different departments, namely Accounting (Bachelor degree), Accounting (Diploma 3), Architecture and Management. The total of them are 100. The participants were chosen because they could provide the best information and they were taught by using Edmodo in the English class. The process of collecting data is based on the research instruments that have been made by the researcher. The instrument is a questionnaire for the respondents to fill in.

\section{RESULTS}

Based on the questionnaire administered to students of Accounting (Bachelor degree), Accounting (Diploma 3), Architecture, and Management who enrolled in General English course, who totaled were all 
308 Celt: A Journal of Culture, English Language Teaching \& Literature, Volume 19, Number 2, December 2019, pp. 302 - 315

adjusted with the number of samples. The result revealed that the majority of students had positive perception on the use of Edmodo during the learning process. Their detailed responses are presented in the table below:

\section{Table 1:}

\section{The Role of Edmodo in Changing Students' Learning Style}

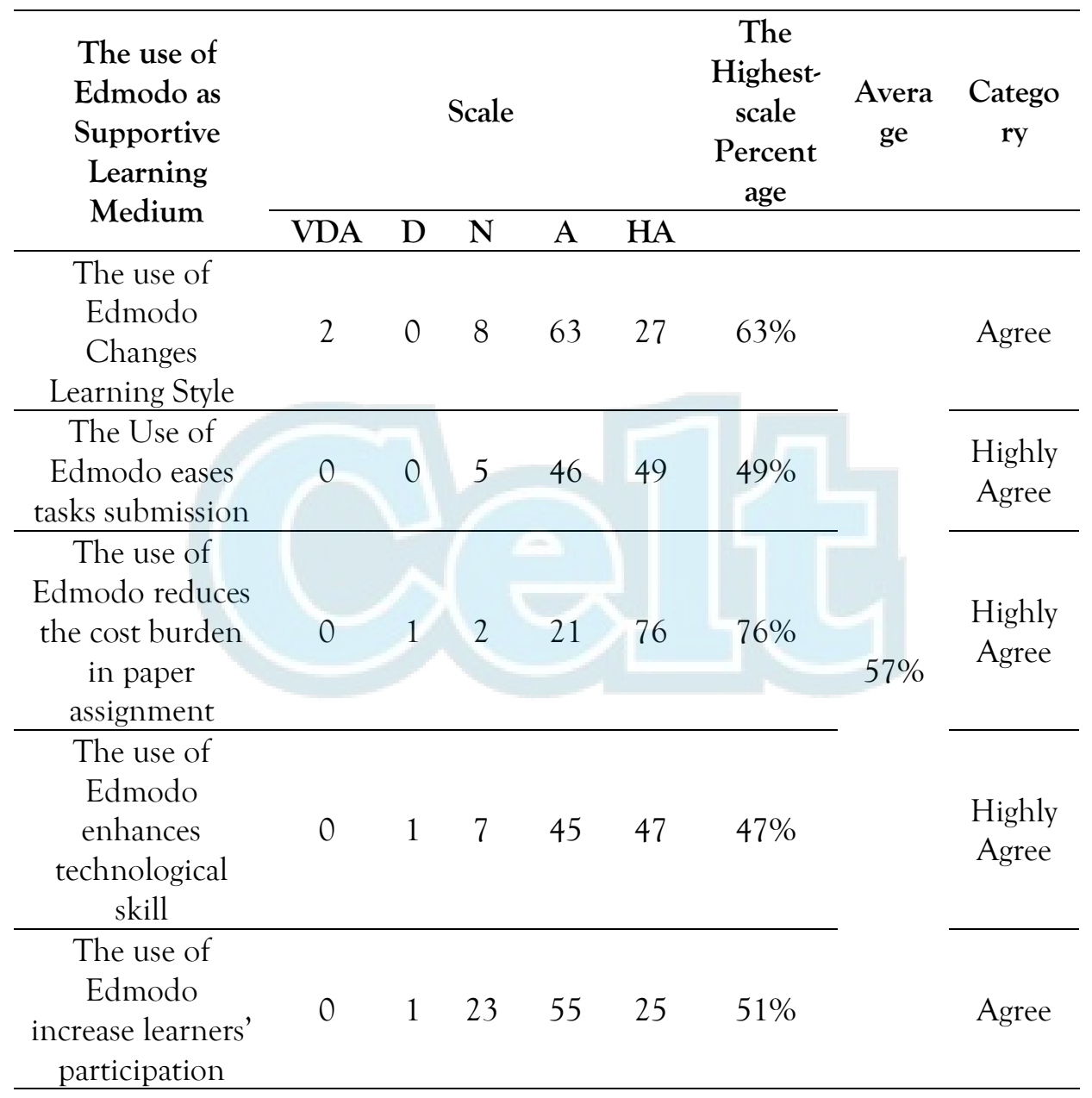

The table above showed that $63 \%$ of the students agreed that this learning application changed their learning style positively. Meanwhile, from 48\% to $76 \%$ of the participants revealed that it assisted them to submit the assignment easily and to save some of their money. 
Tamrin, A. F., Students' Perception towards the Use of Edmodo in Online- 309 Based English Learning Class at Universitas Fajar

About $47 \%$ students said that the application enhanced their technology skills, and $51 \%$ of them showed that it allowed them to become more active. Thus, this can be concluded that students truly supported the use of Edmodo during their learning process. The second table below displays participants' responses on the role and the use of Edmodo when used during the learning process. This includes its convenience, communication between lecturers and students, and course materials delivery.

Table 2:

Students' Responses towards the Role and Performance of Edmodo in English Course

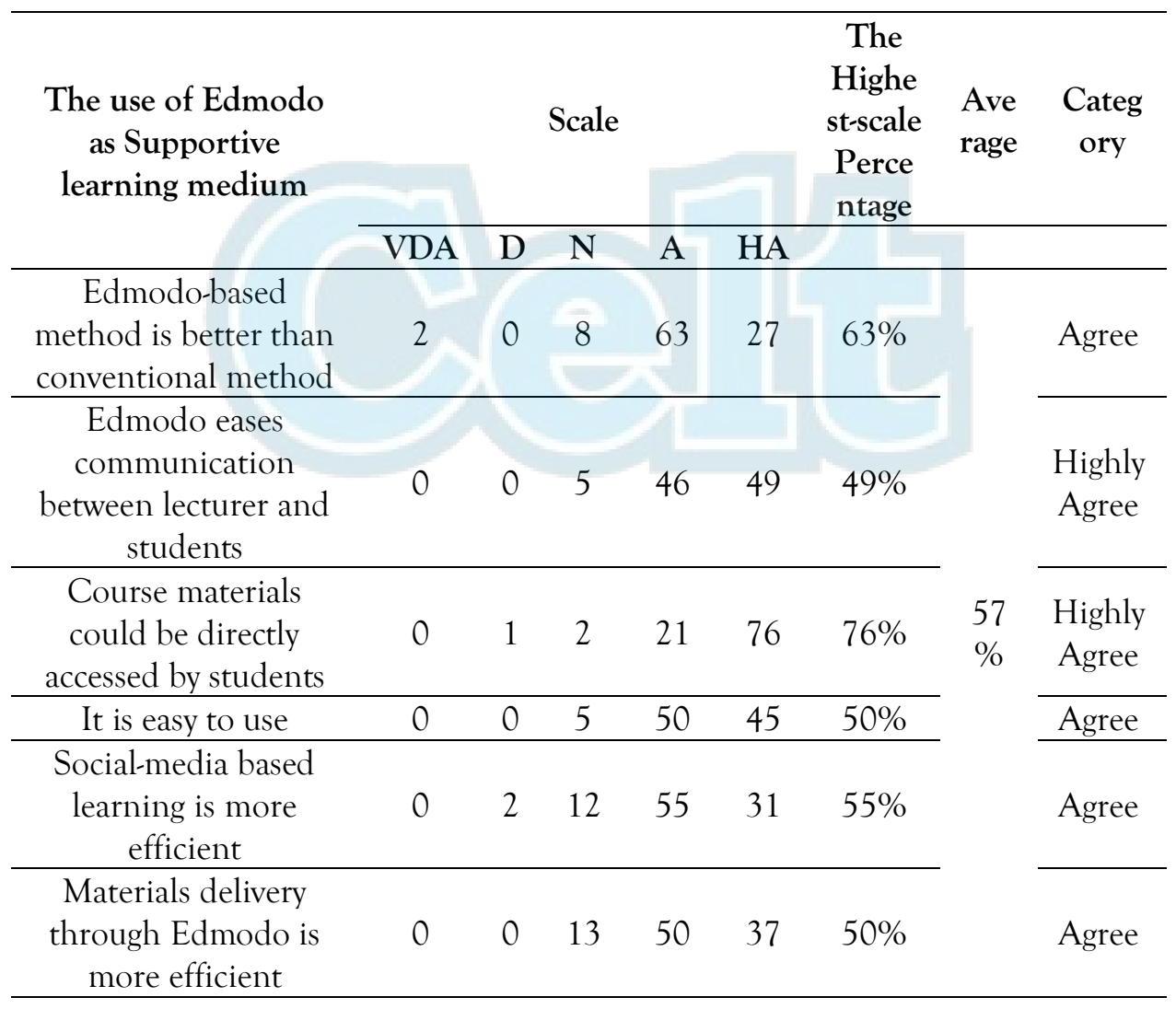

The above table shows that $76 \%$ of participants viewed that the course materials could be received directly through this application while $49 \%$ of them pointed out that they can communicate with their lecturers 
easily. The later finding was surprisingly small if it is compared to the expected ease they should have when communicating with their lecturers.

The table also reveals that 2 students responded "highly disagree" related to the statement that Edmodo-based learning is better than conventional learning method. However, this factor is supposedly caused by the lack of adjustment on the use of the application. On the positive note, the average of $57 \%$ of students agreed with the positive role and use of Edmodo during learning process.

\section{DISCUSSIONS}

The tables above depict information and data about the perception of students on the use of Edmodo in online-based English learning. It is evident that its use has both positive and negative reaction as students have their unique perceptions towards its implementation. The results of the questionnaire show that the majority of the participants support its use as they show "agreement" in 6 out of the total 11 questions and "great agreement" in 5 out of 11 questions.

This finding shows that students' perception on the use of onlinebased learning and Edmodo application could be summarized as (1) onlinebased learning gives tremendous benefits and convenience for students, especially those who have low-level attendance (2) The use of Edmodo during lectures has good acceptance from learners as they no longer have to take a lot of notes during lectures and could focus more on lecturers' explanation since the course materials could be accessed through the application. In addition, it assists them to be more discipline in completing their tasks as the system required them to complete and submit assignments before the due date. Moreover, the application of Edmodo in English class makes the students feel encouraged. Edmodo has quiz section which the lecturer could use to test the students' knowledge. The appearance of it also supports Edmodo in educated students. It has easy language to understand, even students who are slow could easily catch up. Edmodo has its own quiz facility which is presented in English, so that it makes students actively learning English to answer the questions. 
Tamrin, A. F., Students' Perception towards the Use of Edmodo in Online- 311 Based English Learning Class at Universitas Fajar

This research also found out that teaching English by using Edmodo as the media is a very useful tool. Through Edmodo, the lecturer could post the instruction and material for the class. The efficiency of it also interest and coaxed the students to learn more. This statement also supported by the finding of Whiterspoon, A. (2011). Edmodo: A Learning Management System. Retrieved May, 2, 2019, from http://www.poweredwithtechnology.com.

, he found out that Edmodo is a great CMS tool for supporting the teachers to manage their online classes. It also beneficial for them in the use of time.

In terms of providing material for English class, the students could ask more question on the wall if they need more. It is also very helpful for them because the lecturer could maintain the students' learning. By using Edmodo, the lecturer could control and observe them during learning in the classroom. The lecturer is also given advantages by Edmodo. The lecturer could create the sustainable learning even though she is not present in front of the students.

In the term of communication and interaction for students and lecturers, they could build a better relation. In the EFL teaching and learning process, the roles of the lecturer is prominent for the students' performance. This is where Edmodo provide a golden opportunity for both parties, lecturer and student, to interact more. The facilities include real time chat and bulletin board or wall to communicate.

For students, they informed that they could learn easily and they could feel wonderful if they have their lecturer's guide. As for Reading subject, the students can learn more effectively and efficiently. They could freely ask questions that related to their EFL material which have been posted by the lecturer. Based on the finding of this research, this statement has been proven. As much as 87 out of 100 students find it that materials for the subject, especially Reading, is delivered more efficiently through Edmodo Consequently, the students are more enthusiastic in learning English.

Reading activity in English class gets more benefit by using Edmodo as learning media. By posting the reading materials for students to learn, the lecturer could give them more than one material to do. That is why it is 
very efficient and effective. For a reading task, the students could easily access their account from laptops, computers and smartphones. Thus, by applying Edmodo in English class, it is also applying a blended-learning approach, which is lecturing and learning that could be done in the classroom or even out of the classroom all at one time.

Edmodo application is also suitable for teaching and learning. As a learning media based on networking, Edmodo provides a meaningful learning environment to support, strengthen and enhance the learning of EFL. Using Edmodo, is more beneficial for students. The reasons are: Edmodo provides virtual learning and manages students' boredom of learning. This statement is in line with the finding of this research. As many as 63 percent of the students agreed that e-learning using Edmodo is better than the conventional method of learning with the whiteboard. It means that Edmodo encouraged students to learn more by having it integrated to their English lesson. Thus, by using Edmodo, the students could learn a reading subject more effectively and efficiently.

From this research, it also found out that there is a transparency of the students' result of study. because Edmodo provides lecturers two media for giving recognized achievement such as grades and badges. With Edmodo, results of students' work could be seen directly by the students. This method is useful in increasing their motivation in online classes.

The badge that students receive has a function to appreciate the performance of the students. In return, the students could watch the progress of their work, on whether the lecturers have been assessing their work or not. It could be seen from the status of their worksheet. This is in line with the result of the study., where most of the students agree (50\%) that Edmodo is easy for them to use and it is easy for them to see their learning progress for the English class.

Robertson, C. (2008). Integrating of Moodle Management System (CMS) into an EFL Writing Class. The JALT CALL Journal, 4(1), 53-59. Retrieved June 7, 2019, from http://journal.jaltcall.org/articels/4_1_Robertson.pdf (2008) believed, that this kind of e-learning or implementation of technology for learning has positive effects for EFL courses. In this research, it is found that technology has supported many parts of EFL activities, such as the distribution of coursework, the implementation of lesson, the communication and 
Tamrin, A. F., Students' Perception towards the Use of Edmodo in Online- 313 Based English Learning Class at Universitas Fajar

interaction of the lecturer and students, and the most important is to help in creating students center learning experience.

Edmodo'saccessibility is found to be convenient and suitable for students. It is because Edmodo is part of e-learning site, so it could access itanytime from anywhere. Thus, the students have positive attitudes or responses toward this ability. They could learn and consult with the lecturer even though they are not in the same place. It is also convenient because it is a non-stop application that is available for 24 hours to accesses. This statement is supported by the result of the research by Fujimoto (2012), where he found that Edmodo as a free application for learning, allowed the users, in this case the students to access any material, videos and audios whenever the students need or want them.

\section{CONCLUSION}

In EFL learning and teaching, using Edmodo as media is proven useful and helpful. The finding of this research showed that Edmodo is a suitable medium for learning English. Students are found to have a better learning style as a result of their more-practical learning. This is made possible through students who are being more disciplined when completing assignments through Edmodo. Thus far, Edmodo is found to be a great assistance for those who could not attend lectures directly. Nevertheless, as Edmodo is just recently applied, lecturers and students should be aware for some obstacles that may arise or still exist.

\section{ACKNOWLEDGEMENT}

This paper was fully funded by the Ministry of Research, Technology, and Higher Education under the Junior Lecturer Grant.

\section{REFERENCES}

Balasubramani, Kandappan \& Jaykumar , Leena N.K. (2014). Student Preference Towards the Use of Edmodo as A learning Platform to Create Responsible Learning Environment. Proceeding, Asia Euro Conference. Selangor: School of Hospitality, Tourism and Culinary Arts. 
314 Celt: A Journal of Culture, English Language Teaching \& Literature, Volume 19, Number 2, December 2019, pp. 302 - 315

Bentley, Y., Habte, S., and Anjali Shegunshi. (2012). Design and Evaluation of Student-Focused eLearning. The Electronic Journal of eLearning, Volume 10 Issue I, 2012, page 1-12 from http://www.ejel.org/volume10/issue1

Da Luz, Fredson Soares dos Reis. (2015). The Relationship between Teachers and Students in the Classroom: Communicative Language Teaching Approach and Cooperative Learning Strategy to Improve Learning. In BSU Master's Theses and Projects. Item 22. http://vc.bridgew.edu/theses/22.

Fujimoto, C. (2012). Perceptions of Mobile Language Learning in Asutralia: How ready are learners to study on the move? The JALT Call Journal, 8(3), 165-195. Retrieved June 20, 2019, from http://journal.jaltcall.org/articles/8_3_Fujimoto.pdf

Kucirkova, L., Petr, K., and Hana, V.V. (2012). Study Result and Questionnaire Survey of Students in the Lesson of Business English E-Learning Course in Comparison with Face-To-Face Teaching. Journal on Efficiency and Responsibility in Education and Science, Volume 5 No. 3 page 173-184 from https://www.eriesjournal.com/index.php/eries/article/view/63

Looi, C. Y. and Yusop, F.D. (2011). Potential Use of Social Networking Tool to Assist Reading Comprehension: Implications for Practice and Future Research. Jurnal Pendidikan, 31 (1), 189-201 from http://eprints.um.edu.my/9216/

Mazer, J.P. (2012). Development and Validation of The Student Interest and Engagement Scales. Communication Methods and Measures, 6, 99_125.

Nielson, K.A. and Lorber, W. (2009). Enhanced post-learning memory consolidation is influenced by arousal predisposition and emotion regulation but not by stimulus valence or arousal. Neurobiology of Learning and Memory. Vol. 92, No. 1, pp 70 - 79.

Robertson, C. (2008). Integrating of Moodle Management System (CMS) into an EFL Writing Class. The JALT CALL Journal, 4(1), 53-59. Retrieved June 7, 2019, from http://journal.jaltcall.org/articels/4_1_Robertson.pdf 
Tamrin, A. F., Students' Perception towards the Use of Edmodo in Online- 315 Based English Learning Class at Universitas Fajar

Sanaky, H. (2013). Media Pembelajaran Interaktif-Inovatif. Yogyakrta: Kaokaba di Pantara.

Scott, M. (2012). Go Ahead... Be Social: Using Social Media to Enhance the Twenty-First Century Classroom. Distance Learning, 9(2) 54-59 from https://www.questia.com/magazine/1P3-2742042181/goahead-be-social-using-social-media-to-enhance

Struyven, Katrien. (2005). Students' perceptions about Evaluation and Assessment in Higher Education: A Review, Assessment $\mathcal{E}$ Evaluation in Higher Education, 30:4, 325-341 from https://www.tandfonline.com/doi/abs/10.1080/026029305000991 02

Sugiyono. (2011). Metodologi Penelitian Kombinasi (Mixed Methods). Bandung: Alfabeta.

Whiterspoon, A. (2011). Edmodo: A Learning Management System. Retrieved May, 2, 2019, from http://www.poweredwithtechnology.com. 